\title{
A Comparative Study of Bonwire Kente and Daboya Benchibi
}

\author{
Emmanuel Kodwo Amissah* and Ama Pokua Afram \\ Department of Textile Design and Fashion Studies Education, University of Education, Ghana
}

Received: 钢 February 27, 2018; Published: 眥 March 05, 2018

*Corresponding author: Emmanuel Kodwo Amissah, Department of Textile Design and Fashion Studies Education, University of Education, PO Box 25, Winneba, Ghana, Email: erkamissah@gmail.com

\begin{abstract}
Weaving is one of the indigenous crafts, very common in the Ghanaian tradition. This craft is very much associated with three regions in Ghana. These are Volta region in the southern sector, Ashanti region in the middle sector and Northern region in the northern sector. Prominent areas within these regions are AvetimeKpetoe in the Volta region, Bonwire in the Ashanti region and Daboya in the Northern region. Woven fabrics produced from each of these areas possess specific characteristics different from other. The purpose of the study was to ascertain the production processes involved in the manufacturing of Daboya"Benchibi" and Bonwire "Kente". The study aimed at bringing out the similarities and differences in the Daboya"Benchibi" and Bonwire"Kente". The study centred on the qualitative design paradigm and employed the descriptive research method. The study used observation and interview as data collection instruments to identify, describe and analyse the production process, differences and similarities in the production processes of the two weaving traditions.

The purposive sampling was used to select six weavers for the study. Three each from the selected communities. The descriptive method was used to analyse the data. The study found out that designing, warping, heddling, reeding, tying-up and actual weaving constituted the production processes involved in the production of both Daboya "Benchibi" and Bonwire "Kente". The study revealed that Daboya"Benchibi" and Bonwire "Kente" have differences in terms of style of weave, designs and materials used. The study recommends that the physical features, techniques and various skills in these traditions of weaving should be upheld to serve as a unique trademark and legacy for both communities.
\end{abstract}

Keywords: Kente; Benchibi; Weaving; Master weavers; Warp; Weft

\section{Introduction}

Woven fabrics are produced by the process of weaving. Weaving is the interlacing of two or more yarns, using a loom. It is very challenging or even impossible to associate the commencement of any useful art upon which the necessity and comfort of mankind depends on to a particular race or nation. Due to the importance and urgency associated with clothing and other prerequisites of mankind, weaving was done by almost every race in one way or the other [1]. He further traces weaving to as far back as the time of Job of the Old Testament in the Bible when Job did not hesitate to draw a comparison of his life predicaments to that of the swiftness of the weaver's shuttle. This reveals how the ancient art and craft of weaving is, if it can be traced to the era of the Old Testament of the Bible. Rozental [2] narrates that about 20,000 to 30,000 years ago, early man established the first string by twisting together plant fibres. She opines that the early man prepared thin bundles of plant material and stretched them out while twisting them together to produce a fine string or thread. The ability to produce string and thread was the starting place for the development of weaving, spinning, and sewing.

Stone Age Man's early experiments with string and thread led to the first woven textiles. Threads and strings of different sizes were knotted and laced together to make many useful things. Finger weaving, lacing and knotting together of threads by hand, is still used today by many weavers [3]. According to Appiah [4], in Africa, cloths generally, are woven out of fibres; cotton, raffia, straws, barks of trees or plants, like jute and linen. This unravels 
the variations in fibre and other filaments relevant for textile activities of cloth production. However, the principle underlying the technique of weaving remains similar. That is sets of yarns or threads made to interlace at right angles. This textile practice has evolved in many cultures across the world simultaneously and the Ghanaian culture is not left out. In Ghana, this craft of weaving is very much associated within three regions. These are Volta, Ashanti and the Northern regions. Prominent areas within these regions are AvetimeKpetoe in the Volta region, Bonwire in the Ashanti region and Daboya in the Northern region. Woven fabrics produced from each of these areas possess specific characteristics different from other.

The Bonwirekente is of a complex and intricate designs that identifies the rich culture of the Ashanti kingdom. Just like any other society, the people of Daboya being part of the Gonjaethnic group in the Northern Region of Ghana have peculiar forms of arts that also identify them. It is also in these art forms that the Ashanti and the Gonja exhibit some aspect their cultural values such as ethics, attributes and royalties. The woven cloth produced by the Bonwire people is called "kente" characterized by geometric shapes. Daboya is also known for the production of its woven cloth known as Benchibi. The entire fabric is hand woven but in narrower strips and designed with stripes. Weaving is one of the main occupations of these two traditional areas.

Historically, the origin of Kente can be traced back to the weaving traditions of West African kingdoms that thrived between 300A.D. and 1600A.D. Kente is the improved form of the numerous weaving traditions that existed in West Africa preceding the birth of the Asante Kingdom. Samples of strips of woven fabrics were discovered in West Africa in the $11^{\text {th }}$ Century in the excavation of archaeologist. These strips of cloth presumed to be used for burial purposes perhaps during the era of Ghana, Mali and Songhai empires have similar features to many woven cloth in West Africa likewise, the Asante Kente. It is therefore believed that craft men of the Asantes might have learnt weaving skills from their neighbours of the west and north and subsequently polished their skill to come out with their unique style of cloth [5].

The Daboya Benchibi and Bonwire Kente are made into various designs for different occasions like weddings, rituals, funerals, child naming ceremonies and further for leisure and informal occasions. Kente and Benchibi are desirable to be worn by everyone especially on special occasions. Kente and Benchibi have become the attire for national events. The Benchibi cloth is usually used in the production of "Fugu" (smock) Politicians and State officials put on Kente and Fugu during state functions like swearing-in-of the President of the Republic of Ghana and Independence Day celebrations. Eminent citizens of Ghana by wearing Kente and Benchibi have aided in the placement of the two respective cloths as a Ghanaian identity abroad [6].

Bonwire Kente and Daboya Benchibi are prominent and important media by which Ghanaian cultural heritage can be preserved. Kente and Benchibi are irrefutable evidence and have utmost impact so far on the cultural heritage of Ghana. These woven fabrics have been done over the centuries and are one of the famous traditional arts in Ghana. However, similar the weaving process are, there are inherent differences that are characterised in the nature of materials, tools, accessories and equipment that these traditions of weaving poses. The study therefore was to ascertain the production processes involved in the manufacturing of Daboya Benchibi and Bonwire Kente, The study also aimed at comparing and contrasting the materials, tools, accessories and equipment used in the weaving processes of these two weaving traditions in Ghana.

\section{Methodology}

The study is situated in the qualitative paradigm of research. Creswell et al. [7] describe qualitative paradigm as an inquiry approach in which the inquirer explores a central phenomenon of a one key concept, asks participants broad, general questions and collects detailed views of participants in the form of words, images or words and images. Qualitative research is characterised by its aims, which relate to understanding some aspect of social life, and its methods which (in general) generate words, rather than numbers, as data for analysis [8]. Thomas [9] explains qualitative studies as those in which the descriptions of observation are not typically expressed in quantitative terms, but not suggesting that numerical measures are never used. Rather, other means of descriptions are emphasised. Sidhu [10] describes that qualitative research emphasises holistic description of whatever is being observed rather than comparing the effects of a particular treatment. This means that in qualitative inquiry, there is an exhaustive description of a particular activity or situation so that whoever has not witnessed the phenomena may have the opportunity to understand whatever is being studied. These formed the basis on which the study was conducted. The descriptive and observation research methods were employed. The descriptive method encompasses describing and interpreting what exist at present in the form of conditions, practices, processes, trends, effects, attitudes and beliefs [11]. Descriptive research method scrutinises the situation as it is and does not operate the situation under investigation nor is it anticipated to verify cause and affect relationship.

The researchers chose the descriptive research to reveal the current materials, tools, equipment and the step by step processes involved in the weaving of the Benchibi and kente withoutinfluencing the situation under study. The direct observation technique which was also employed by the researchers for the study, helped by providing a checklist to systematically conduct and record relevant data. Observation also helped in the verification and nullification of the information provided in the face to face interviews. The researchers observed the environment within which the weaving takes place, design, production process and finishing of the end product. The data was transcribed and assembled in text and pictorial form critically analysed and discussed. 
The population used for this study was master weavers in Daboya and Bonwire. The selection for this study was based on immense consideration of their total commitment and contributions to the maintenance of the weaving tradition among the people of the two communities of Daboya and Bonwire. The purposive sampling was used to select six master weavers from the communities for in-depth study, three from each community. This confirms Kothari [12] assertion that items in the sample are selected deliberately by the researchers, the choice of which remains supreme for the researchers.

\section{Discussion}

The discussions for this study are done in two main categories. These are:

A. The processes prior to weaving and the weaving processes

B. Accessories, tools and materials.

\section{Processes Prior to Weaving and the Weaving Processes}

Designing: Design is a conscious activity, guided by aims and objectives. It refers to planned and organized actions intended to bring about some predetermined outcome although there may also be accidental or unexpected results [13]. This clearly reveals that before one produces a design, the item, artefact or product to be executed should be perceived in mind. Kirkpatrick [14] describes design (verb) as creating or fashioning of an object, form or function, the process of making a drawing, pattern, or sketch of something to show how it will look like, to conceive and plan out in the mind Design in the light of a noun is described as the arrangement scheme of something, a pattern for decorating something a drawing that shows how something will be made or what it will look like, a plan that someone has in mind. From the interviews the respondents said designing is the first step of the weaving process. During the designing, one has to decide on the colours to form the background of the cloth and the colour that would form the weft. The weavers called the activity "colour mixing".

The length and width of the cloth and the number of strips to be woven is also determined at the stage of designing. The kind of motifs and patterns (design) to weave are also considered. Hardt [15] states that five factors are important in designingFunctionality, aesthetics, long-range identity, cultural, political and ethical relations. The weavers in Bonwire and Daboya do not design on paper because of the manner of their training. That is the weavers are trained to design out of memory. This indicates that designing is an essential aspect of creative disciplines as established by Tettehfio [16] that designing is an integral aspect of product development and as such, the Bonwire and Daboya weavers are involved in designing even though this is not done on paper.

Designing is the foremost and considered the most important step in the pre-weaving process. During designing, the weaver decides on the weaving pattern, the colour to use, the length and width of the cloth as well as the number of strips required to obtain a complete cloth in one's memory before commencing the weaving process. The capability to ascertain and blend colours and pattern to achieve an aesthetically pleasing piece is an excellent novelty of the weaver. Adu-Akwaboa [17] adds that design can simply be an arrangement of accepted elements following certain principles. The elements which include lines, shapes, colours, texture, form, tone and light form the building blocks with which the work is constructed. This is what the weavers from this tradition do.

\section{Warping}

Straightening or stretching of the background yarns is executed after designing. The background (warp yarns) lay according to the width, yardage and design of the cloth. The width of the cloth is sometimes dependent on the design to be woven. For instance the width of the Bonwire kente "Angelina" (name given to a designed woven cloth) is wider than the width of a Benchibi named "kayitiwala". All the respondents from Bonwire affirmed that the stretching is done on wooden pegs (ntenennua) inserted into the ground with a device called "menko me nam" (literally meaning "I walk alone") or "baanu ye nna". (Literally meaning "two are better than one"). Warping is done by going round with the warp yarn around a metallic pegs (kenyabi) that are driven into the ground. It was observed that two spools of yarns were placed on the ground. The yarns were passed through a looped metallic guide called "katentenyambi" in Gonja language which is usually fixed at the top of the weaving shed before going round the metallic pegs. Both respondents from Bonwire and Daboya admitted that before the stretching process, the weaver has to consider the weather since the process is done outside in the open. Care is taken ensure that the weather clear.

This is because, if it rains the yarns will get wet, entangle and destroyed. The respondents from both Daboya and Bonwire agreed that warping is a very wearisome process. This point out that warping is the next stage that comes after designing in the weaving process, where long yarns that run lengthwise (warp) of the woven fabric is put together as confirmed by Asmah [18]. Among the Asantes, warping is known as "ntomatene" (straightening the cloth) while the Gonjas refer to the process as "katente". The Bonwire weavers do the warping with the use of several spools arranged on a device known as bobbin carrier. This is referred to as "menko me nam/ Baanu ye nna" in Asante. Weavers of Bonwire drove wooden pegs whilst weavers in Daboya drove metallic pegs into ground and yarns are moved around the pegs which are wide apart to obtain the total length and number of warp ends required for the cloth. The wooden pegs are called "ntenennua" (straitening) in Asante and the metallic pegs are called "kenyabi" in Gonja.

The warp yarns are normally prepared a little longer than the exact length of the cloth, to provide allowance for shrinkage and unpredicted wastage during weaving. The crosses created are 
carefully preserved by holding them together with a cord before the warp is removed from the pegs. In removing the warp, the yarn wound around the last peg farther away from the crosses is first removed. After this, the entire length is wound by folding the warp around the hand which is latter removed and spirally wound to reduce the warp to a convenient length for easy handling (Figures $1 \mathrm{~A} \& 1 \mathrm{~B})$.

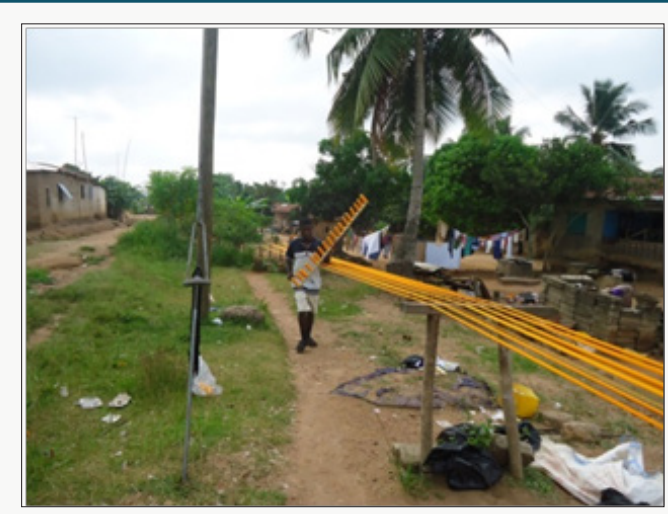

Figure 1a: A weaver warping in Bonwire.

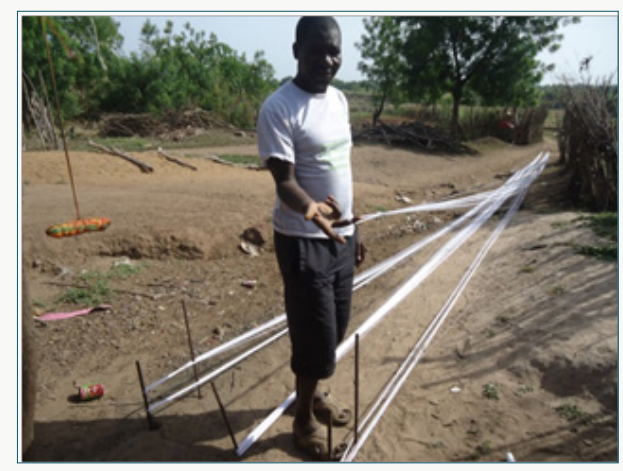

Figure 1b: A weaver in Daboya taking off the warp yarns from the metallic pegs (kenyabi).

\section{Heddling}

After stretching the yarns that forms the background of the cloth, the background yarns are then passed through the "asa" or "aniri". These processes are called "hyehye" (arrange) in Asante and "kapewonta" in Gonja. Bonwire loom has two sets of heddles "asa", the first set is "asatia" (short heddles) that is responsible for plain weave and the second set "asanan"(four heddles) which controls the design weave whilst the Daboya loom has only a set of heddles "aniri" that is responsible for the plain weave. In the kente heddling process a set of yarns are passed through the "asanan" and then the yarns are spread through the "asatia". Respondents from Daboya said two yarns are combined and then passed through the "aniri" (heddles) with the help of the fingers.

This shows that after warping, the warp ends are ready to be passed through the eyes of the heddles ("asa" and "aniri"). This heddling process is also referred to as "drawing-in" by Appiah [4] and Coffie [19]. The heddling is known as "kepawonta" and "hyehye" in Gonja and Asante respectively. The kente loom is equipped with two pairs of heddles. The "asatia" and the second pair is "asanan". The first set is usually retained for plain weaves whereas the other set is reserved for the design weave. This ensures that two different categories of heddling are done on the kente loom which functions concurrently. The heddling is usually began with the design category with bundles of the warp in four or six being inserted through the individual heddle eyes of the design heddles to cover the whole total of warp ends and on completion, these bundles of warp are then divided and inserted through the heddles of the plain weave heddles (asatia).

The Benchibi loom is provided with only a pair of heddles known as "aniri". This is used for plain weave which is the only technique of weave in Daboya. The warp yarns are made into two ply and inserted into the eyes of the individual healds. The middle part of the heddles is usually left empty without a yarn in order not to leave the ends of the heddles empty and to facilitate shedding, a weaving operation described by Adu-Offei, Coffie, Sackey [1921] as raising alternate warp yarns to create an opening called a shed. The heddles with the yarn are referred to as "aniri" while the heddles without the yarns are called "aniribawu". Leaving some of the heddles with warp yarns is also dependent on the number of healds in the heddle (Figures 2A \& 2B).
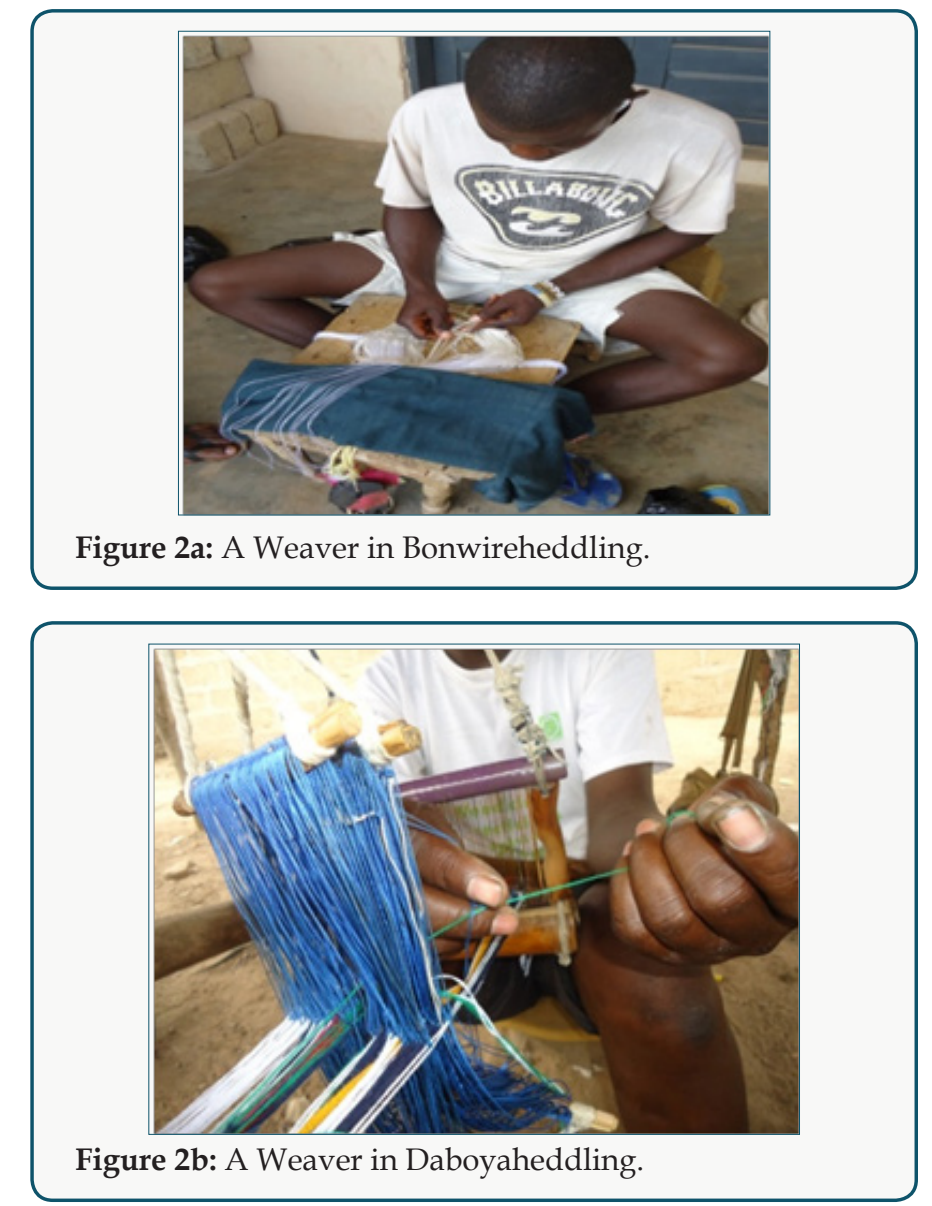

\section{Reeding}

The next process is the reeding, which is passing the yarn through the dents of the reed. The reed is known as "kafa" or "peri" 
in Gonja language and "kyere" in Asante's language. The warp yarns are spread through the reed according to the width of the cloth. Reeding is called "kepawuntakafato" and "hyehye" in Gonja and Asante languages respectively. Respondents from Daboya said the warp yarns are grouped in fours and then passed through the reed with the fingers whiles respondents from Bonwire said the yarns are made into two ply before inserting through the dents of the reed with the help of a small stick. This reveals that reeding follows heddling which involves passing the heddled warp ends through the dents of the reed. This process necessitates the distribution of warp to the required width of the cloth. Thus, the reeding determines the width of the cloth. In the process, each warp yarn from the heddles is inserted through the dent of the reed. Amankwa \& Oppong [3] state that the selvedge yarns are usually doubled to strengthen the edges of the fabric. However, this is not done during the reeding process of both Kente and Benchibi (Figures 3A \& 3B).

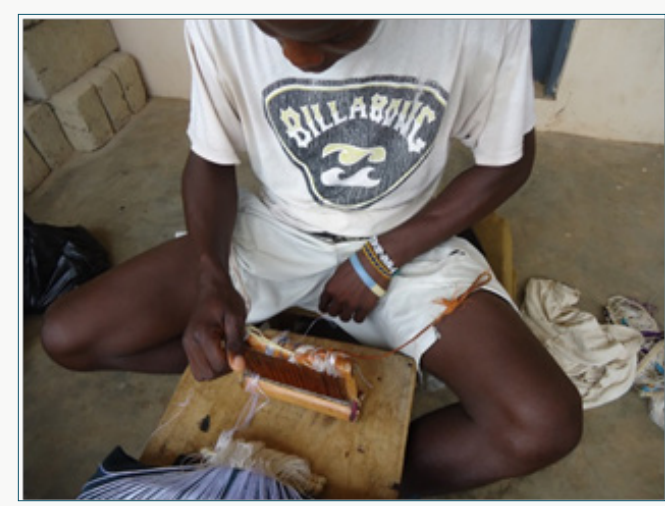

Figure 3a: A weaver reeding in Bonwire.

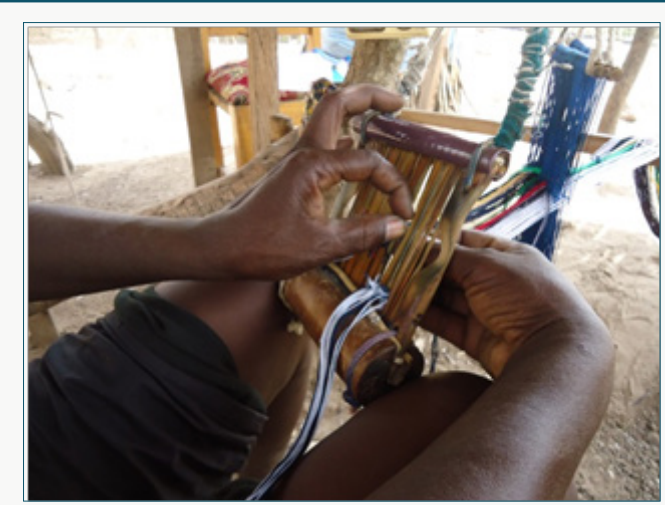

Figure 3b: A weaver reeding in Daboya.

\section{Tying-Up}

The next process after reeding is fixing the warp yarns to the cloth roller known as "kamasidibi" in Gonja and "ayaasedua" in Asante. Tying -up is called "kekerewutakamasidibi" in Gonja and "ntomatibo" in Asante. The warp is then attached to the "tweso" or "kagberi". The cloth roller is then rolled to stretch taut the warp yarns. It must be ensured that the right tension is obtained. Respondents in Daboya and Bonwire revealed that the warp ends are first knotted to a small stick which is connected to the cloth roller with cord. This small stick is called "kebilempo" in Gonja. This shows that, at this stage of the weaving process, warp ends are attached to the cloth roller. The reed and heddles are at this stage tied up to the pulleys and hanged onto bar at the top of the loom. The wound warp is then unrolled, stretched and attached to a drag weight known as "tweso" in Asante and "kagberi" in Gonja. The cloth roller is then revolved to ensure the right tension in the warp. After this, the warp is then tied up to the cloth roller. The warp tensioned yarn is called "ntomaasaase" in Asante and "katenyijesey" in Daboya (background of the cloth). The process of tying up is known as "kekerewutakamasidibi" and "ntomatibo" in Gonja and Asante respectively (Figures 4A \& 4B).

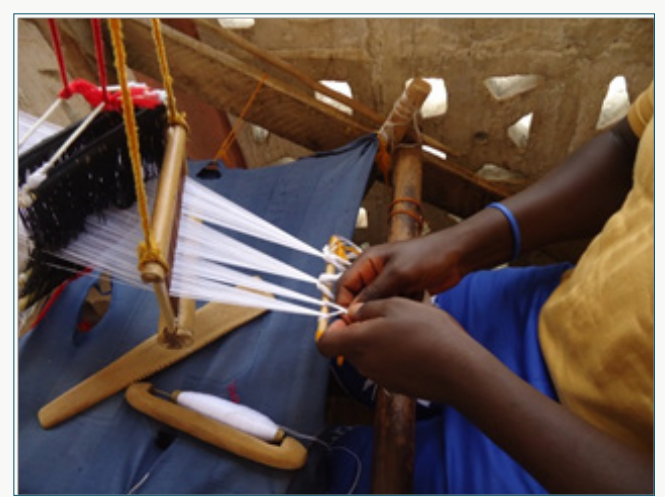

Figure 4a: A Kente weaver tying up.

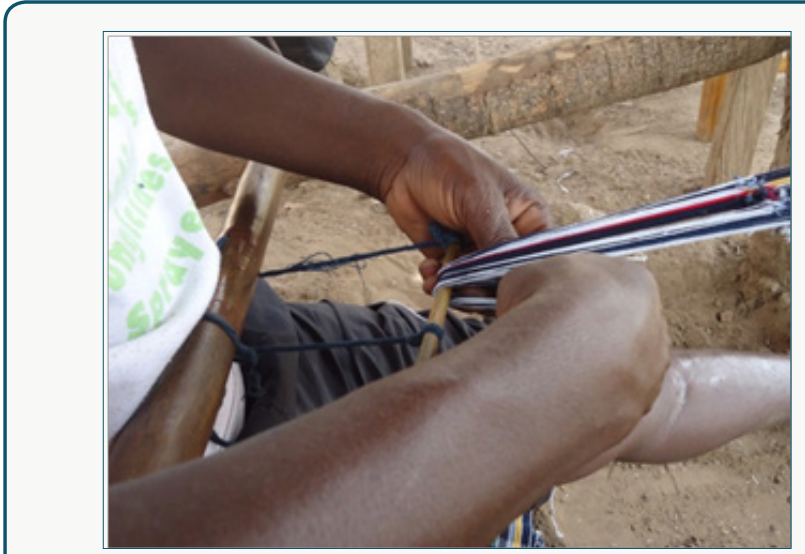

Figure 4b: A Benchibi weaver tying up the warp on the small stick (kebilempo) attached to the cloth roller (kamasidibi)

\section{Weft Preparation}

According to the respondents from the interview, Daboya weavers prepare only a set of weft yarns for weaving. The weft yarn is usually locally dyed with blue-black locally prepared dyes with some parts remaining white (as a result resist-dyeing method). Bonwire weavers usually employ two sets of yarns, one in the shuttle and the other set for hand picking design which is not contained in a shuttle. During weft preparation, yarns in hank are fixed onto skein winder and a spool rack respectively and wound onto bobbins with the help of a bobbin winder. Yarns on cones are wound onto bobbins directly with bobbin winder. This reveals 
that amongst Bonwire weavers, two sets of weft yarns are usually utilised and these are the binding weft usually carried in a shuttle and the pattern weft which is handpicked. Pattern wefts are usually thick as a result of arranging many yarns together depending on the design to be created and also to determine the weight of the fabric to be produced. During weft preparation, yarns in hank are fixed onto skein winder and a spool rack respectively and wound onto bobbins with the help of a bobbin winder. Wefts of different colours are prepared in accordance with the number of colours meant for the design. Several bobbins are wound to facilitate quick weaving process. In Daboya, only one set of weft which is of one colour is prepared for the weaving. The weft is carried in a shuttle during weaving. The process of preparing the weft yarns is simpler than warp yarns as affirmed by Adu-Offei [17] and Asmah [18]. This process is referred to as "mfamu" or "ahomaboro" in Asante and "kamligikadoro" in Gonja (Figures 5A \& 5B).

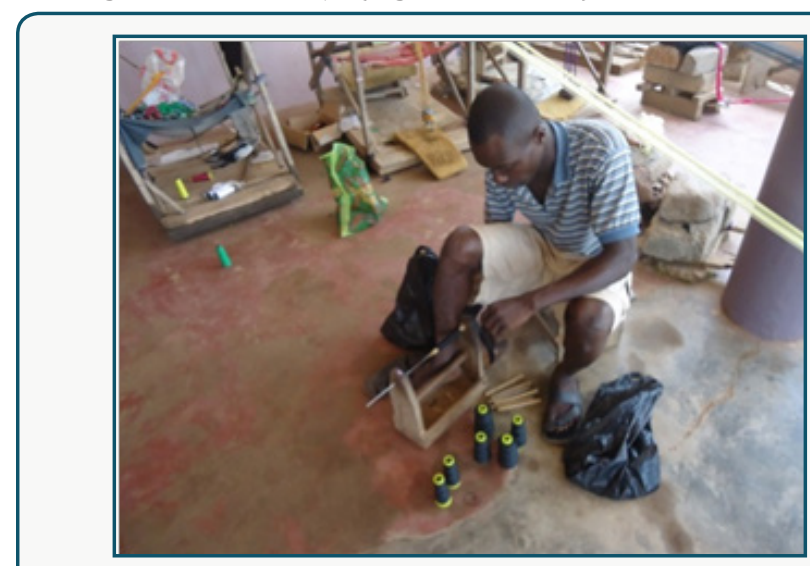

Figure 5a: A weaver in Bonwire preparing the weft.

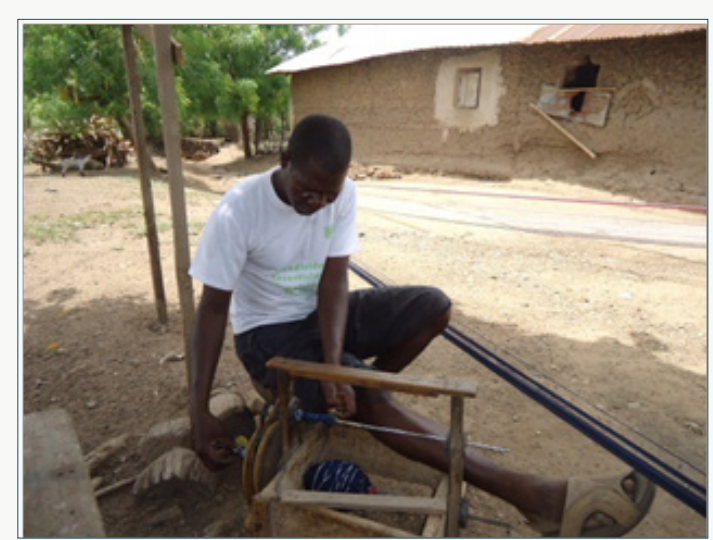

Figure 5b: A weaver in Daboya preparing the weft.

\section{The Weaving Process}

The respondents expressed that in weaving, the treadles are pressed down to create a space between the background yarns and the weft yarn is left between the spaces left. The weft yarn is then pushed to the end of the cloth by the reed. Respondents from Bonwire expressed that when weaving Kente, one has to know how to weave "ahwepan" (plain weave) and the design weave (adwene). In weaving the plain weave, it was observed that only the shuttle containing the weft was used. The design weave employed the hand in picking the weft yarn in accordance with the design to be woven. It was found out that during weaving (ntomadwene) of Bonwire Kente, a treadle (ntiamu) is depressed to open a shed. A shuttle containing the weft (plain weave) is thrown through the shed from one side of the loom to the other. This operation is referred to as picking by Adu-Offei, Coffie, Fiadzo, Sackey [17-21]. The treadle is released and the weft beaten-up with the reed. The process is repeated alternatively until the required plain weave is produced.

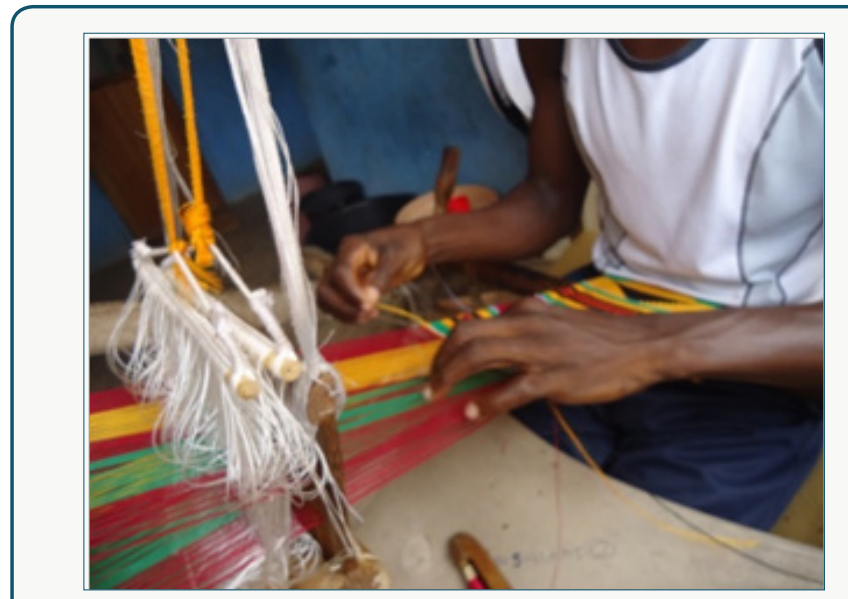

Figure 6a: A weaver weaving in Bonwire.

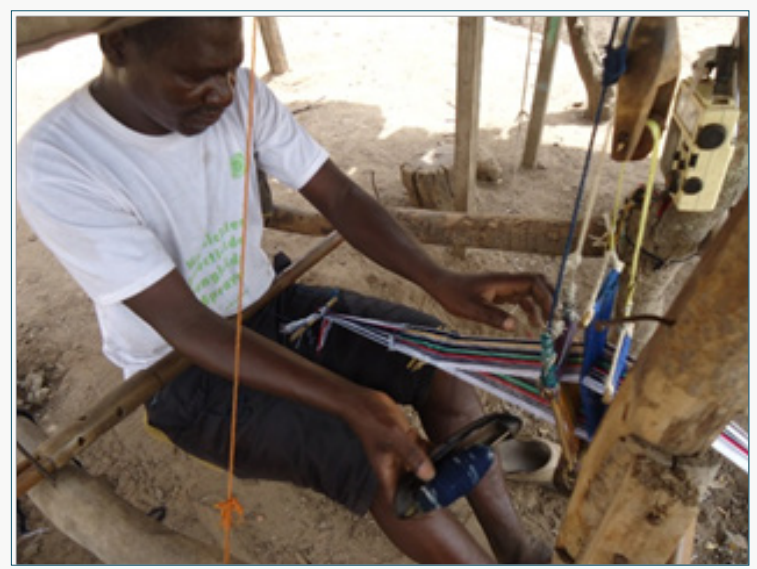

Figure 6b: A weaver weaving in Daboya.

In the case of designing the weave in Bonwire, the treadle that controls the design heddles is pressed and a design weft inserted with the finger along the part of the warp that corresponds with the design. The treadle is released and the inserted design weft beatenup with the reed. After a design weave, a plain weave is done to bind it. In some situations, a swordstick (tabon) is used to keep hold of the shed before the handpicking is done. After a complete design, the plain weave is repeated to bind the design. Weaving the Daboya Benchibi, a treadle (aniribaya) is depressed to open a shed. A shuttle containing the weft is thrown through the shed from one side of the loom to the other. The treadle is released and the weft beatenup with the reed (kafa/peri). The process is repeated alternatively until the completion of the entire cloth. There is no hand picking 
since the cloth is produced only with the plain weave technique. The process of weaving is called "kalor" in Gonja (Figures 6A \& 6B). Having identified the various processes involved in the weaving of Daboya Benchibi and Bonwire Kente, Adu-Offei [17], Amankwa \& Oppong [10], Sackey [20] agree with the processes identified in the study as being designing, warping, heddling, reeding, tie up, weft preparation and actual weaving. However, beaming as identified by Adu-Akwaboah [21] is not among the processes involved in the manufacturing of Kente and Benchibi.

\section{Accessories, Tools and Materials}

Materials: The main material for weaving is yarn. The basic character of a woven fabric depends largely on the type of weave structure and the type of yarn used. According to the respondents, the final nature of a cloth is determined importantly on the type of yarns used for the weaving. This is very important in the sense that the type of yarn has effect on the final cloth. Daboya weavers expressed the use of factory spun cotton yarns for their weaving. They said, they used to weave with the hand spun yarns, spun by the women of Daboya in the olden days [22]. The hand spun yarn is thick, rough and heavy hence cloth produced from this yarn is heavy and rough but durable. From the weavers, cotton yarn is used for weaving their cloth since mostly; the yarn is locally dyed before weaving.

On the other hand, weavers from Bonwire said, they weave with cotton, polyester and rayon yarns. Cotton is best used for the black and white cloth called the "Fufuontoma" since the white cotton yarn which dominates the cloth brightens well than rayon. Rayon and polyester yarns are good for the multi-coloured cloth. According to them, the preferred yarn for design weave is rayon. Hence, in the shortage of rayon yarn, some weavers have to put on hold weaving for another time until the rayon yarn is available. Previously, they used to use silk yarn which is the best of yarn but has been replaced with rayon when the silk yarn is in scarcity on the market. Rayon and polyester yarns are used for the design weave. The rayon yarn is very fine and soft and the draping effect of the cloth is desirable. Cotton is preferable for the plain weave (ahwepan) to make the cloth heavy. This shows that the type of yarn material is very crucial to a weaver to be capable to attain a quality work. The type of yarn determines the durability and qualities such as drape, thickness and stiffness of the cloth.

From the study, weavers in both Daboya and Bonwire weave with cotton yarns. The cotton yarns are best used for the plain weave as confirmed by Adu-offei [17], Glime [23].Cotton is desirable for plain or single weave to make cloth a little denser. From the study, rayon and polyester yarns are utilised in Bonwire Kente but not used in the weaving of Daboya Benchibi. Weavers of Bonwire prefer and commend to weave with rayon and sometimes polyester yarns for the design weave. It is the preference of weavers in Bonwire to utilise rayon and polyester for the design weave because rayon yarn is thin and soft which makes the woven cloth flexible and drape well as affirmed by Asmah [18]. Cotton when used for design weaves results in a stiff, lowly finished cloth as well as reduction in draping effect of the cloth (Figures 7,8).
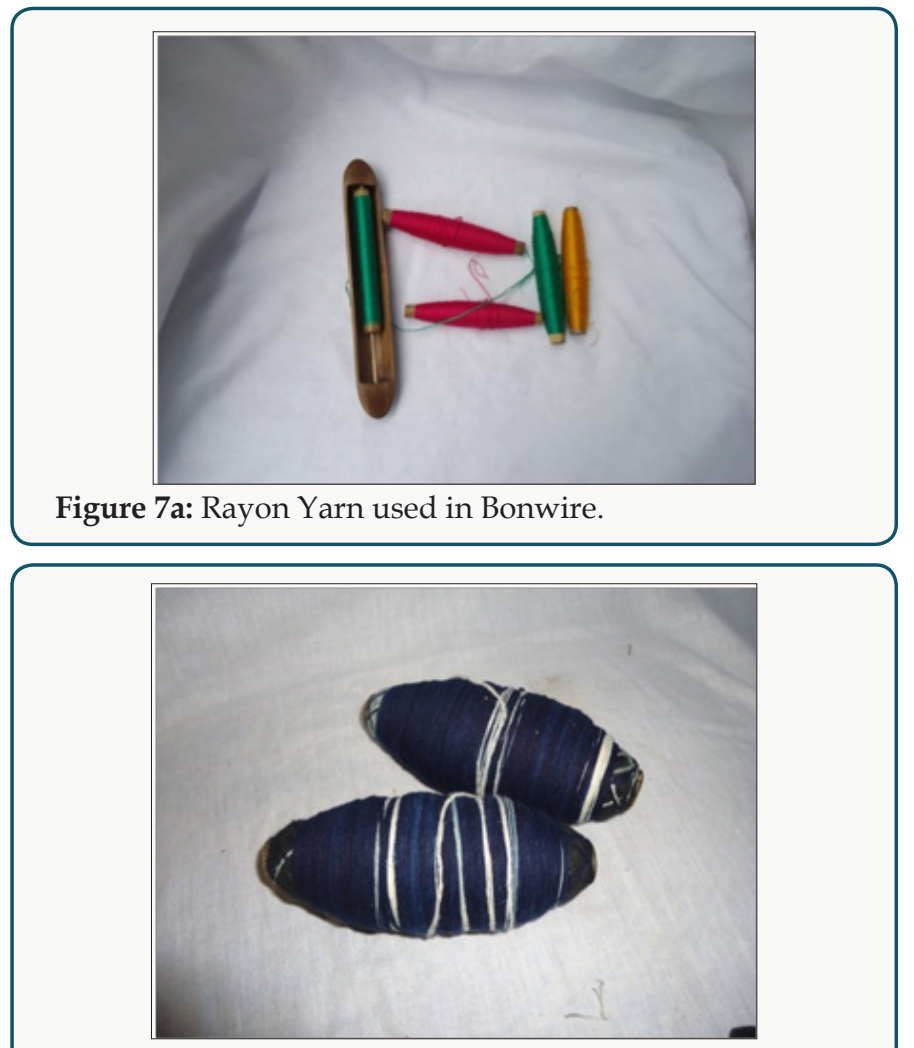

Figure 7b: Cotton yarn dyed and used in Daboya.

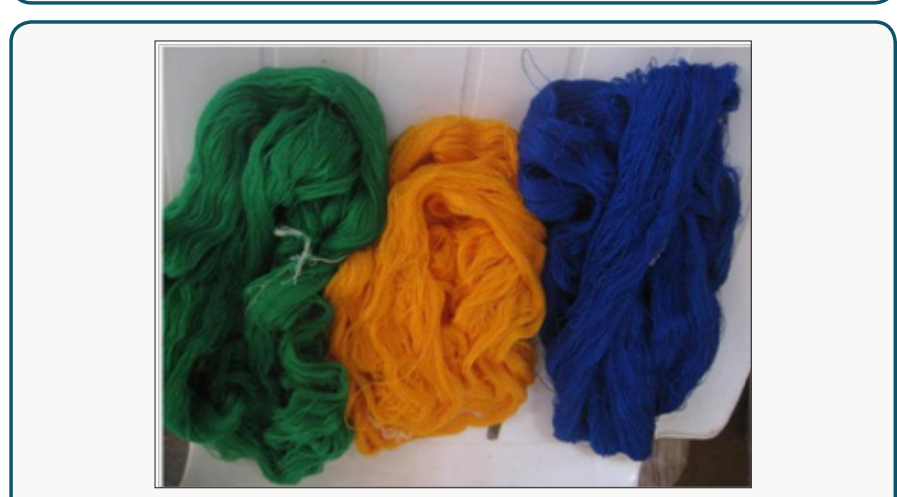

Figure 7c: Factory-dyed cotton yarns used in Bonwire.

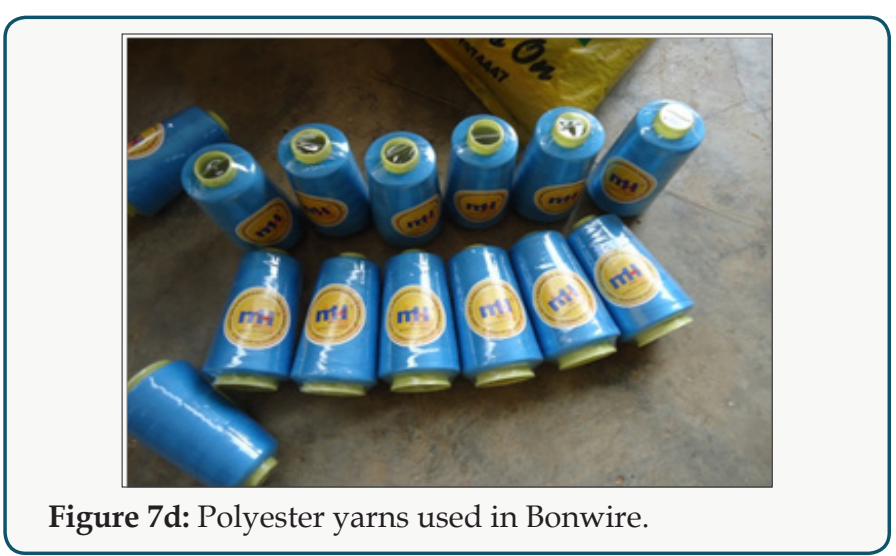




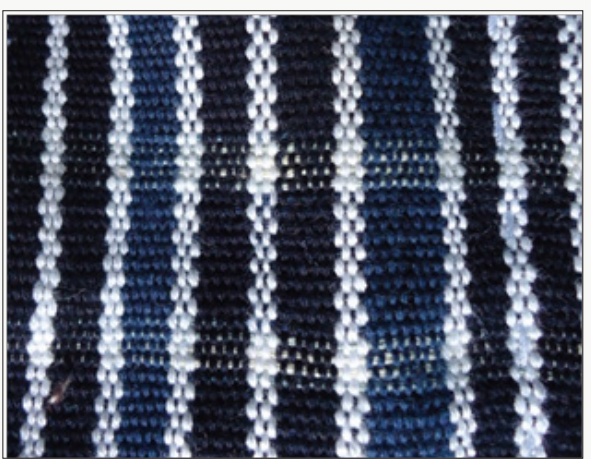

Figure 8a: Sample cloth of "Benchibi".

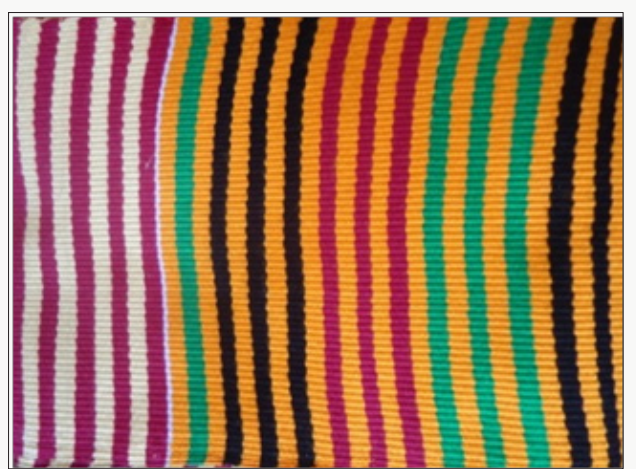

Figure 8b: Sample cloth of "kente".

\section{The loom (Tool)}

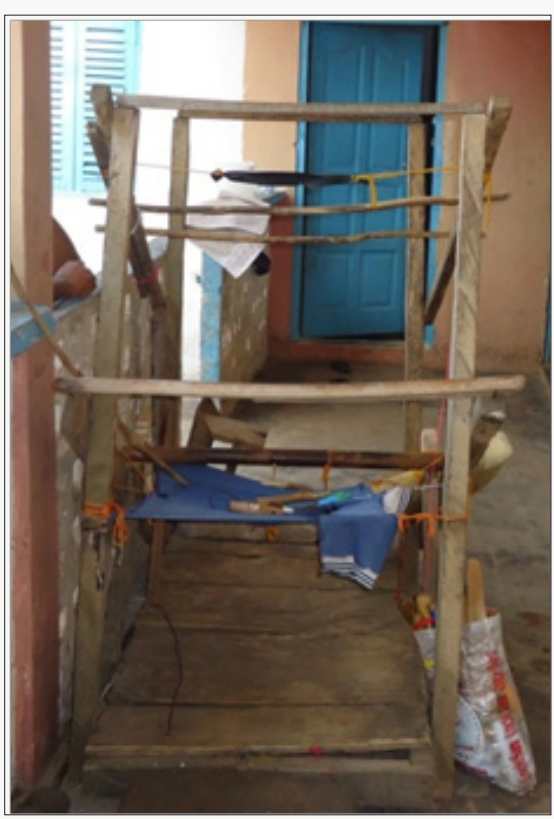

Figure 9a: Mobile loom at Bonwire.

The loom called "korey" in Gonja and "nsadua" in Asante is made of wood. The loom is the main frame on which weaving is done. The "nsadua" is constructed in wood and in such a way that the "nsadua" is mobile. It can be carried from one place to the other. Respondents from Daboya said the "Korey" is constructed by inserting logs of wood into the ground where the weaver wishes to weave. This is done by the weaver himself with assistance of friends, family members who may be weavers. The "nsadua" and the "korey" are made of wood. Nonetheless, the "nsadua" is a mobile loom constructed by carpenters. Thus, it can be placed anywhere provided there is enough space for the stretched warp and its drag weight. The "korey" is an immovable loom with similar parts as the "nsadua". It is shorter than the "nsadua" and it is made of tree log cut from the bush by the weaver and then fixed to the ground (Figures 9A \& 9B).

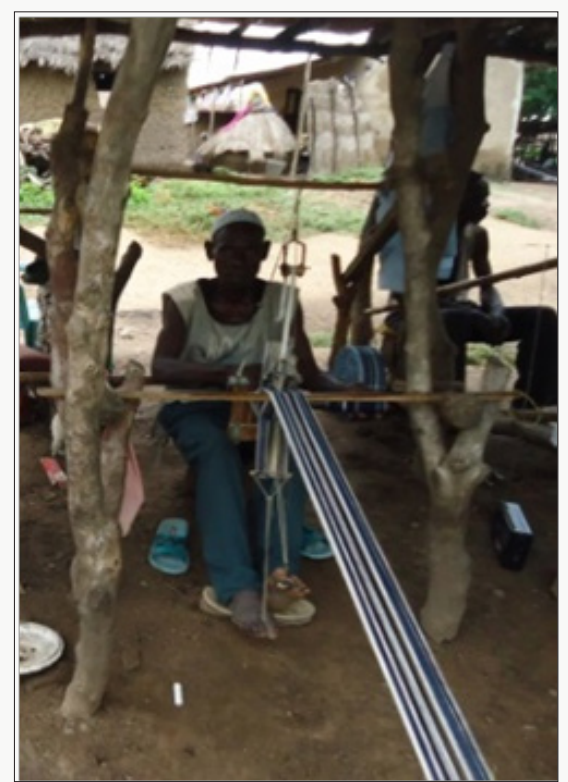

Figure 9b: Fixed loom of Daboya.

Accessories

A. Heddles: This is called "aniri" in Gonja and "asa" in Asante. The heddles is a rectangular device consisting of two resilient sticks one at the top and the other down and joined by fine strings with loops in the middle of each string. The warp passes through the loops in the middle of the string (Figure 10).

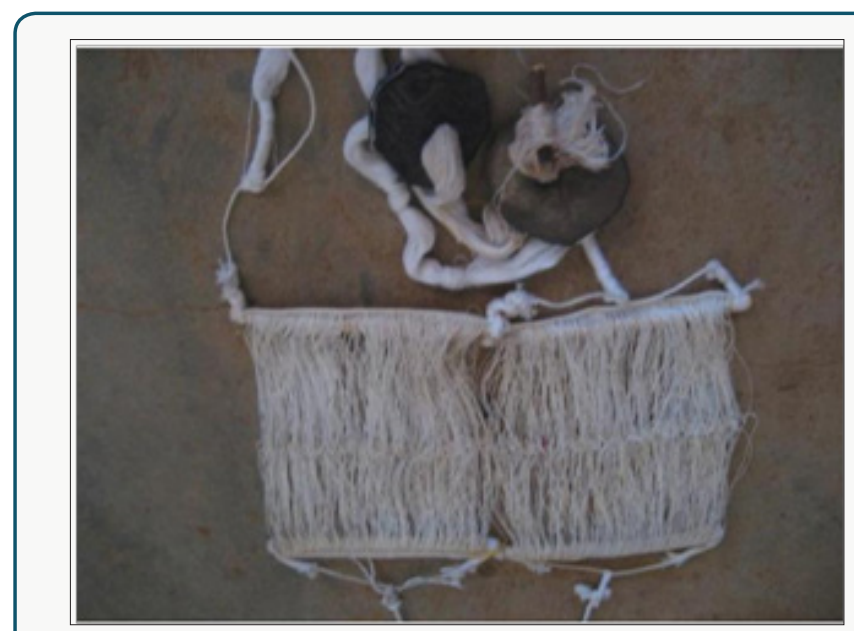

Figure 10: Heddles. 
B. Bobbin: This is a piece of bamboo ("prampro" in Asante and "kachebi" in Gonja) with a hole that carries the weft for weaving. Bobbin is known as "kadoro" and "drodowa" in Gonja and Asante languages respectively (Figure 11).

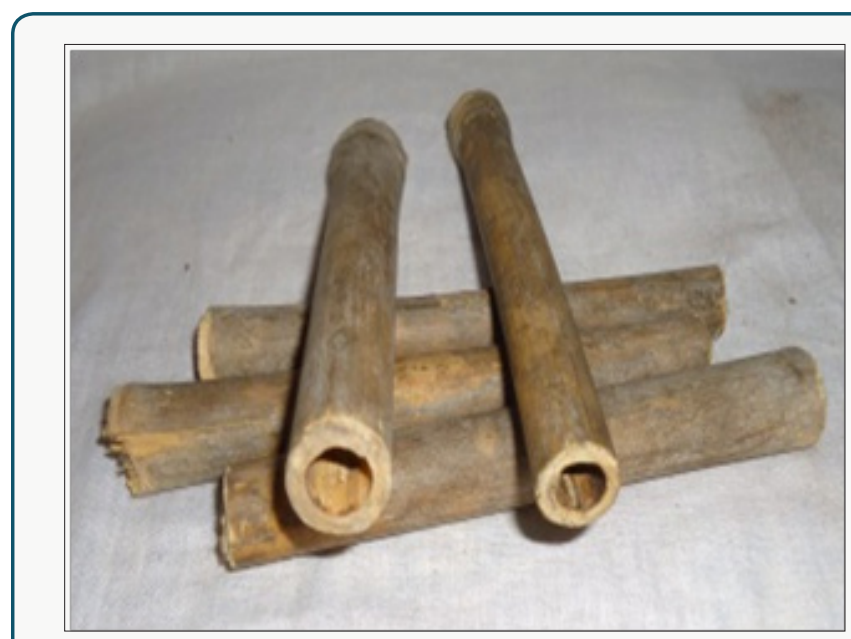

Figure 11: Bobbin.

C. Reed/beater: one of the most important accessories in weaving Benchibi and Kente is the reed or beater. This is known in Gonja and Asante respectively as "peri" / "kafa" and "kyere". The size of the beater or reed determines the width of strip to be woven. The beater is rectangular in shape, built of two fine strips of bamboo with holes cut at each end, joined by reeds. The reed is suspended by two strings from a beam across the top of the loom (Figure 12).

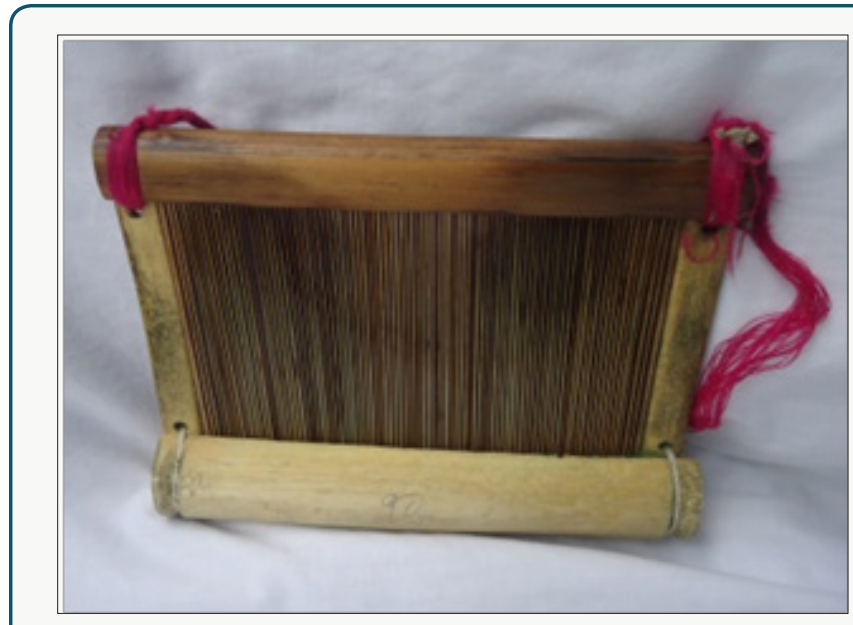

Figure 12: Reed.

D. Seat: This is sat on when weaving. Some of the weavers in both Daboya and Bonwire put foam or pillow on the stool for comfort sitting during weaving. Stool is the seat typically used by weavers. Yet pieces of logs and spoilt mortars serve as seat for some weavers. Bonwire weavers mostly use the stool while Daboya weavers mostly sat on pieces of logs and abandoned mortars (Figures 13A \& 13B).

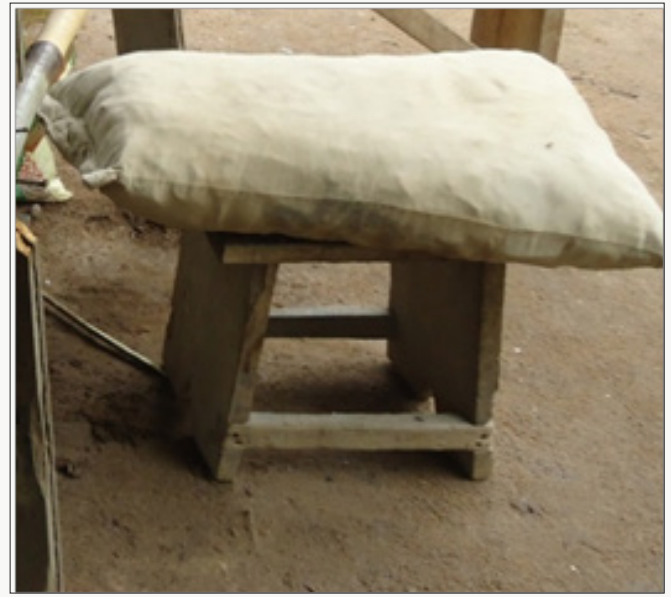

Figure 13a: Stool with a pillow used in Bonwire.

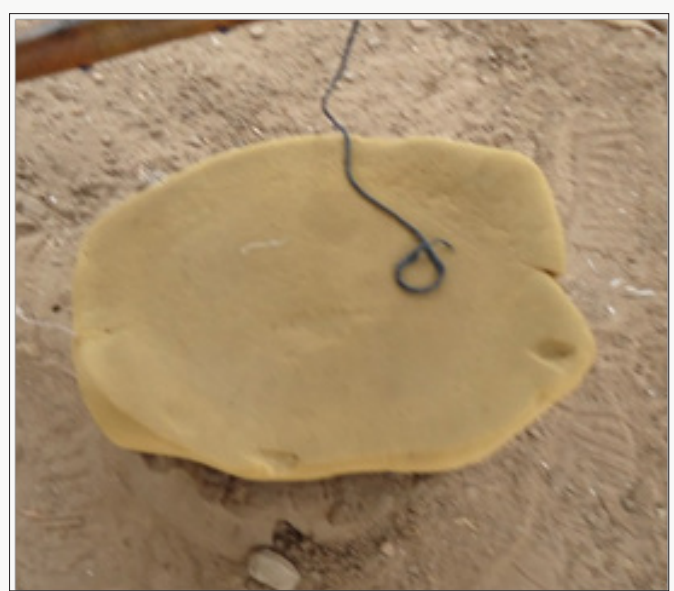

Figure 13b: Mortar with foam used in Daboya as seat.

E. Cutting edge: This may be scissors, knife or blade which is used for cutting strips of cloth from the cloth roller and excess and unwanted threads from the woven cloth (Figure 14).

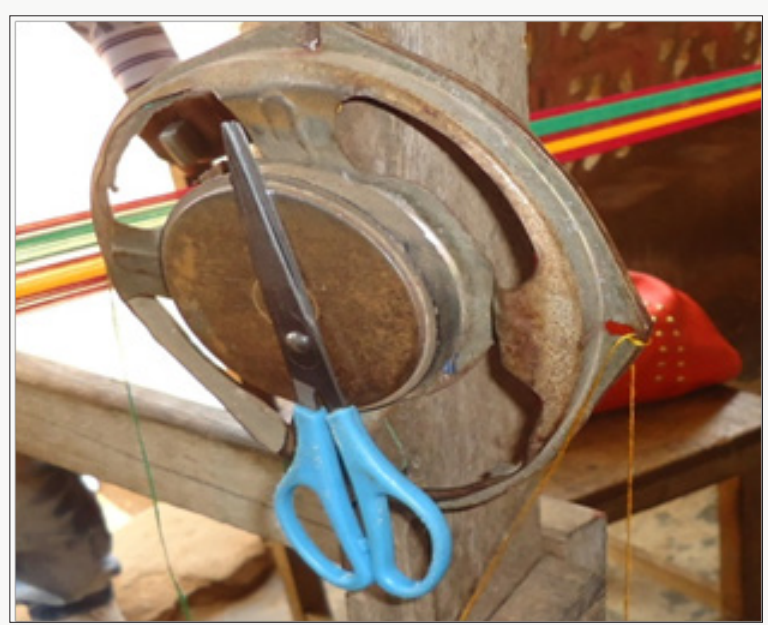

Figure 14: Scissors. 
F. Shuttle: this is used for passing the weft in between the created shed in warp. This is passed back and forth through the shed between the warp yarns. It is made of wood, smooth and boat-like. This is called "gambo" and "krokrowa" in Gonja and Asante respectively (Figures 15A \& 15B).

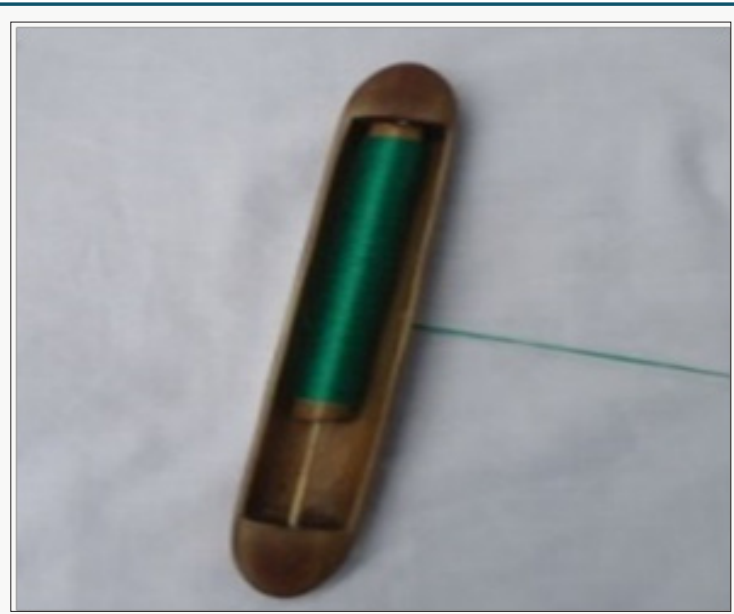

Figure 15a: Shuttle with bobbin used in Bonwire.

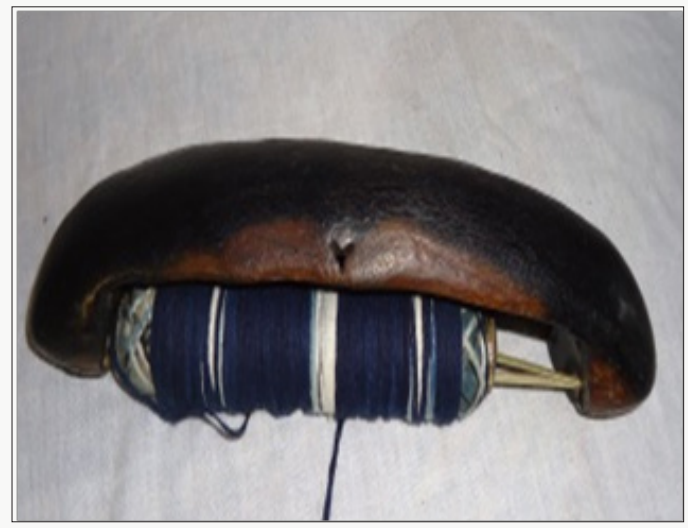

Figure 15b: Shuttle with bobbin used in Daboya.

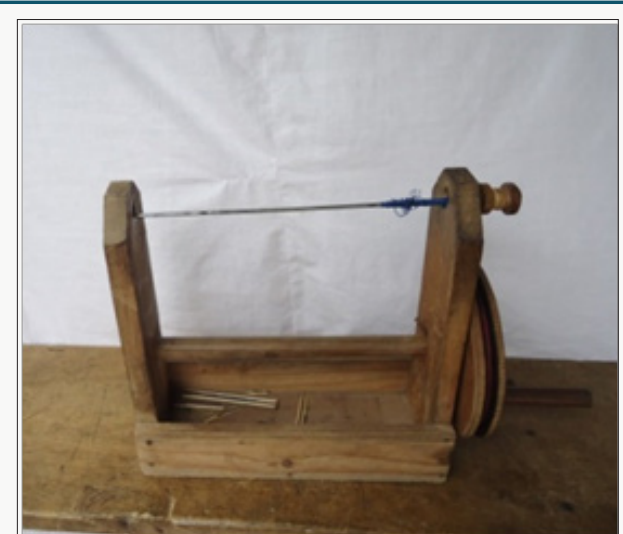

Figure 16a: Bobbin winder used in Bonwire.

G. Bobbin Winder: A device used for winding yarn onto bobbins. This is called "krokro" and "afidie" in Gonja and Asante respectively (Figures 16A \& 16B).

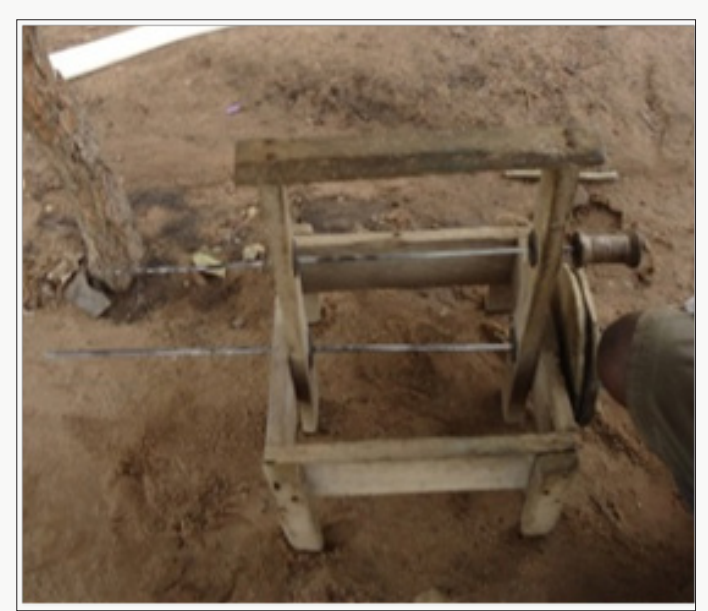

Figure 16b: Bobbin winder used in Daboya.

H. Skein Winder: This device known as "hwiridie" in Asante and "fan" in Gonja is used for unwinding hanks. This rotates for the yarn to be rewound onto bobbins. The rotational nature of the device helps the weavers to wind their yarns onto the bobbins (Figure 17).

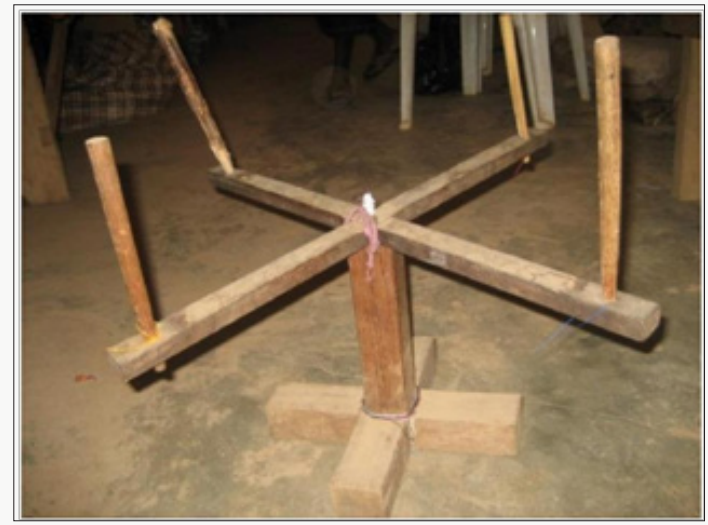

Figure 17: Skein winder.

I. Drag weight: This helps to keep taut the warp. This is known as "kagberi" and "ntweso" in Gonja and Asante respectively (Figures 18A \& 18B).

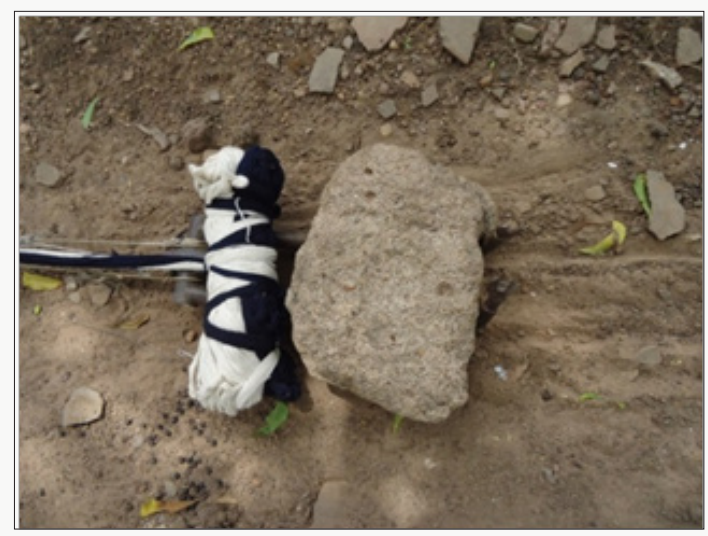

Figure 18a: Drag weight used in Daboya. 


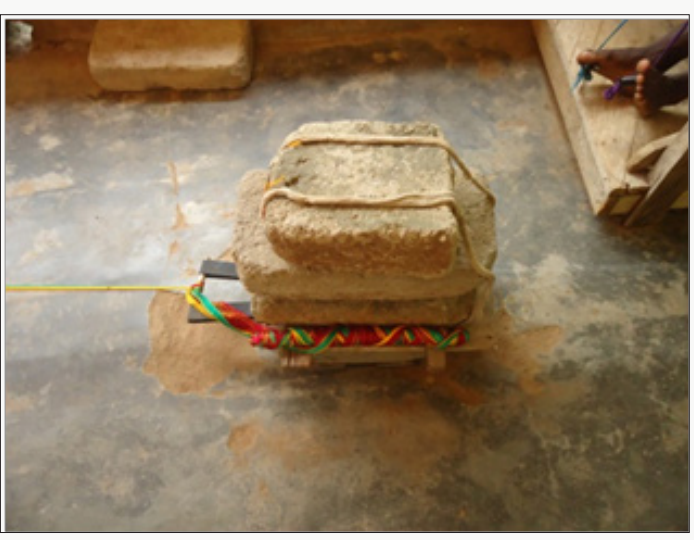

Figure 18b: Drag weight used in Bonwire.

J. Treadles: This is depressed to create the shed during weaving. Treadles are known as "aniribaya" and "ntiamu" in Gonja and Asante respectively (Figure 19).

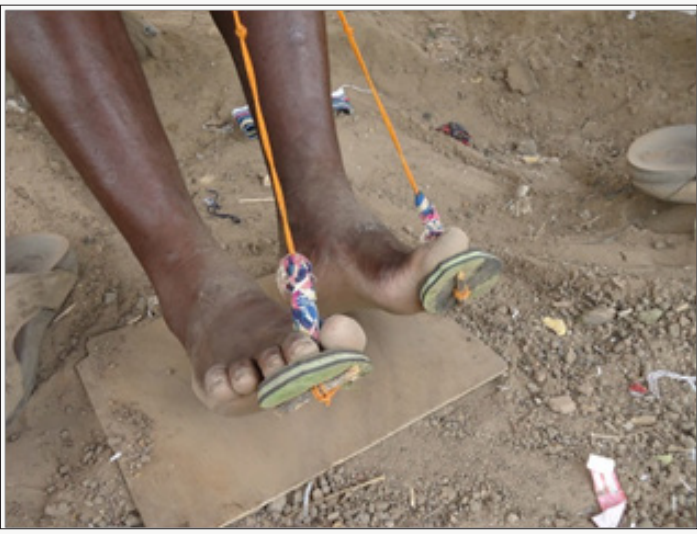

Figure 19: Treadles.

i. Distinctive tools and Equipment used

ii. There are specific implements that are peculiar in the production of Bonwire Kente and Daboya Benchibi. These weaving implements include:

a) Shed Stick: The shed stick is used to maintain a shed when design weave is being woven. This tool is peculiar to weavers of Bonwire but not used in Daboya (Figures 20A \& 20B).

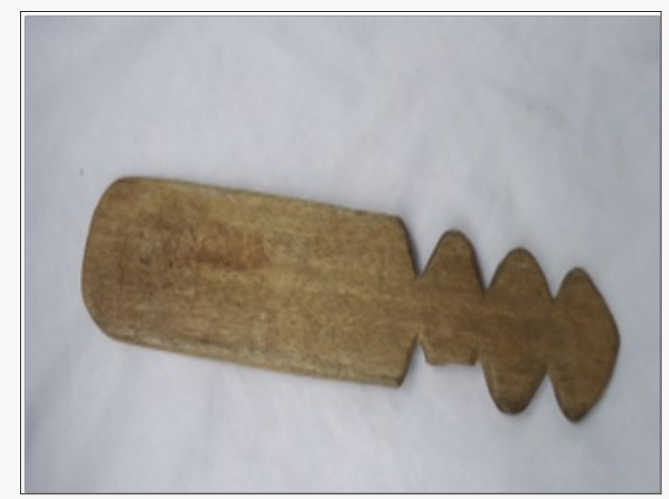

Figure 20a: Sword stick.

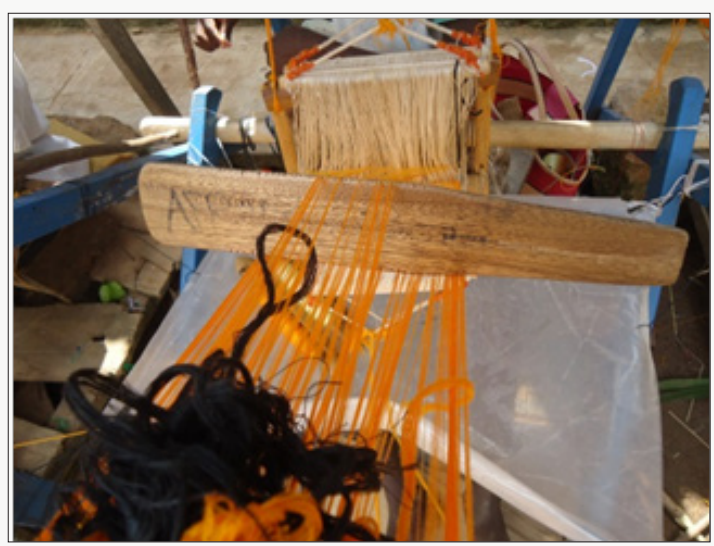

Figure 20b: Sword stick inserted in the warp.

b) Spool Rack: This device is known as "menko me nam" or "baanu ye nna". It is used in Bonwire for warping (Figure 21).

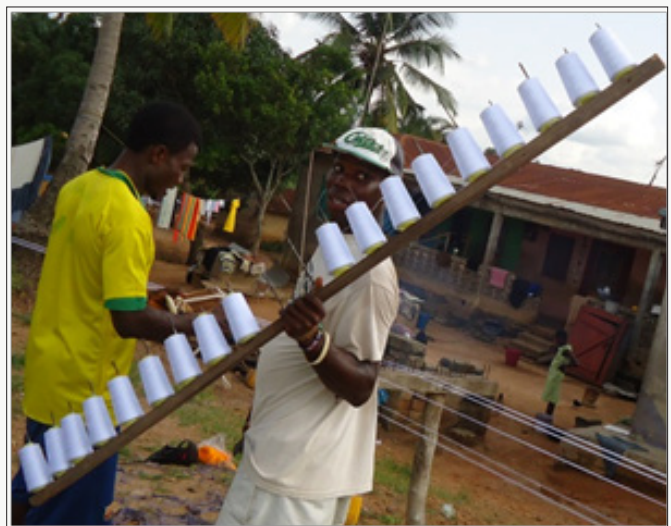

Figure 21: A weaver with the spool rack.

c) Thread Guide: This device is unique to weavers in Daboya. It is called "katentenyambi" and it guides the warp during warping (Figure 22).

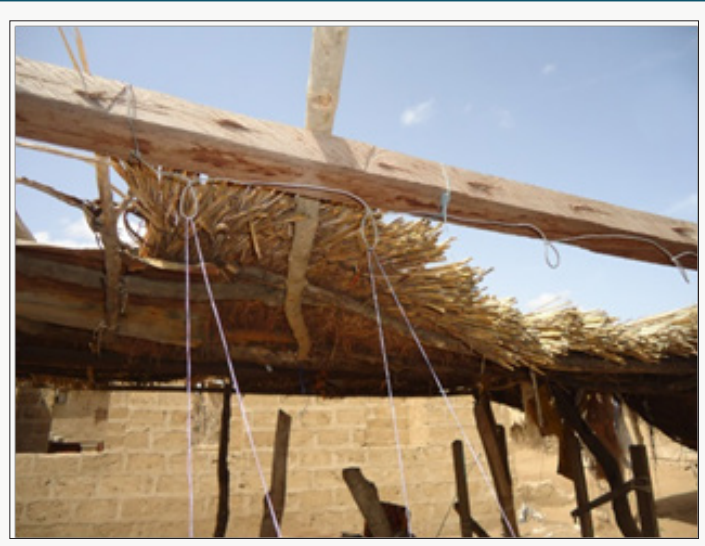

Figure 22: Thread guide (katentenyambi).

\section{Weaving Area}

It was observed that weaving goes on in Daboya outside (under trees and hurts constructed by the weavers themselves). Bonwire weavers were similarly noticed weaving outdoors under trees and 
hurts built by the weavers themselves. However, some weavers in Bonwire were found weaving on verandas, porches at the comfort of their homes as well as indoors- in houses and well-constructed sheds. No weaver was detected weaving indoors or on verandas in Daboya due to the immobile nature of the loom they used. Weaving areas were generally neat and tidy in both Daboya and Bonwire weaving towns. This reveals that weaving has to be done at a shady and cool area to enable one to weave for a long time. Weaving under the scorching sun is not a permissible condition for weaving. Weaving is done under a conductive condition and not harsh environment. Weaving is not supposed to be done in an unclean and filthy environment.

\section{Duration for Weaving and the Type of Weave}

According to the respondents of both Bonwire and Daboya, the period of time for weaving a particular cloth depends on the design to be woven and the length and width of the cloth. Daboya weavers claim it takes 2-3 days to weave a standard cloth. Bonwire weavers say that it may take between one and four weeks to weave a simple design and two to six months to weave complex designs. They said, usually the length of a cloth is determined by the gender use of the cloth, thus whether the cloth will be used by a male or a female. Kente weavers revealed that, the length of women cloth is six yards whilst that of men is between eight and ten yards depending on height of the individual. It was observed that Benchibi weavers employ plain weave and with warp yarns being more visible than the weft yarns. Kente weavers employ both plain weave and design weave. With Kente, the weft yarn is very conspicuous, concealing the warp yarns.

\section{Conclusion}

The study described the production process involved in the manufacturing of Kente and Benchibi by the people of Bonwire and Daboya respectively. The study outlines the processes in the production of woven fabric as designing, warping, heddling; reeding, tie-up, weft preparation and actual weaving. The study found that weavers of both traditions in spite of modernity still employ crude and outdated production processes. The study also found out that both Kente and Benchibi can be produced using factory spun cotton yarns and characterised by various types of lines. However, Daboya weavers principally utilise hand spun cotton yarns manufactured and dyed locally in Ghana. They believe this will help in maintaining the tradition of smock production. They also believe that the hand spun cotton yarn brings out the uniqueness of the fabric produced, hence, the unique nature of the smock. Kente is woven with factory spun cotton and rayon yarns imported from other countries. The multi-coloured yarn provides the kente cloth with its unique character. Weavers in Bonwire use portable mobile looms that could be placed in a room or veranda for weaving whiles weavers in Daboya operate with looms that are fixed to the ground on open space limiting weaving to be done only when the weather is favourable. These two traditional communities have been able to maintain this ancient craft of weaving in Ghana.

\section{Recommendation}

In the interest of cultural maintenance, weavers in the woven industry, in spite of modernity, still employ crude and outdated production processes. Modern and advanced technology could be introduced by research institutions to help improve the weaving of Kente and Benchibi. Weavers of Bonwire Kente and Daboya Benchibi should utilise a weaving apparatus known as the warping mill to ease the work load and energy exerted during warping. Rain will not hinder warping since the warping mill can even be used indoors. Yarns used in weaving Bonwire Kente are imported from other countries. The government and investors should setup a yarn manufacturing factory in Ghana to feed the Bonwire weaving industry. Daboya weavers should maintain the use of cotton yarns manufactured in Ghana and dyed locally in Daboya in order to help sustain both the textile factory and the Daboya local dyeing industry. Weavers in Daboya should adopt the mobile looms that can make it possible for weaving to be accomplished in rooms and porches, so that the activity of weaving will not be dependent on the weather.

\section{References}

1. Barlow A (1979) The history and principles of weaving by hand or power $\left(2^{\text {nd }} e d n\right)$.

2. Rozental J (2009) Weaving design. History of weaving.

3. Broudy E (1979) The book of looms: a history of the handloom from ancient times to the present. UPNE, New York, USA

4. Appiah ERK (2004) The visual arts; general knowledge and appreciation $\left(2^{\text {nd }} e d n\right)$, Takoradi-Ghana: St. Francis Press, Ghana.

5. Ofori Ansa K (2012) Ashanti Kente Cloth-More than a piece of fabric. A part of Culture.

6. Abugri GS (2008) The Fugu Dr Kwame Nkrumah gave the world. Daily Graphic, Africa.

7. Adu-Akwaboa S (1994) Art (revise Edn), Kumasi-Ghana: Samarg.

8. Creswell JW, Clark VL (2009) Principles of Qualitative: Designing a qualitative study. Lincoln: Uni Press, Ghana.

9. Patton QM, Cochran M (2002) Guide in using qualitative research methodology. New York-Harcourt Race Publishers, Ghana.

10. Thomas RM (2003) Blending qualitative and quantitative research methods in theses and dissertations. Corwin- Volumes Discounts, ERIC.

11. Amankwa S \& Oppong H (2002) Basic essentials in textiles. Kumasi: Bernadettes.

12. Burns N, Grove SK (2010) Understanding nursing research: Building an evidence-based practice. Elsevier Health Sciences.

13. Kothari CR (2004) Research methodology: methods and techniques $\left(2^{\text {nd }}\right.$ edn) New Age International Publisher, New Delhi, India.

14. Jacobson J (2011) Transforming accidental adversaries dynamics in client systems and ourselves.

15. Kirkpartrick EM (2002) Design. (In D.Abercrombie, Eds: A. Christenson Chambers Dictionary). London: Clark Constable, pp. 113.

16. Hardt M (2006) Design the term design. 
17. Tettehfio LA (2009) The role of indigenous Ghanaian textile industry in relation to the President's Special Initiative (PSI) on Textile and Garments (unpublished doctoral dissertation) KNUST- Ghana.

18. Adu-Offei K (2004) Introduction to textile technology. Accra- Ghana: Danites Press, Ghana.

19. Asmah AE (2004) Ashanti traditional Kente. Kumasi, Ghana

20. Coffie DA (2009) Textiles made easy. Accra-Ghana: Anest Publication, Ghana.
21. Sackey J (2002) Introduction to textile technology; Fabric manufacturing. Accra: Frank Publishing, Ghana.

22. Fiadzo SV (2010) Weaving techniques in college of education using variety of media. Unpublished master's thesis. KNUST, Ghana.

23. Glime OA (2007) Raw materials in textiles. Kumasi, Ghana.

\section{(C) (?) \\ This work is licensed under Creative Commons Attribution 4.0 License}

To Submit Your Article Click Here: Submit Article

DOI: $10.32474 /$ LTTFD.2018.01.000121

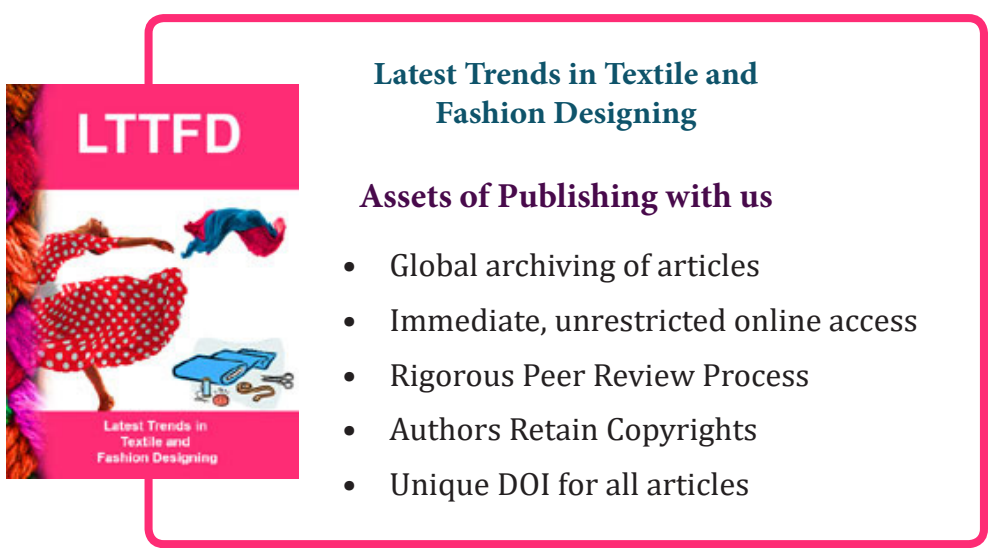

